\title{
Humanistic Principles in the Circle of European Literature Themes
}

\author{
Gordana Pokrajac \\ Philosophical Faculty in Novi Sad
}

\begin{abstract}
There is the question - can we hope that humanism and erudition can redevelop nowadays? In the long history of humanistic inheritance, from ancient times till the end of the 18th century, there was obvious decadence of essential humanistic points. As the historial period, humanism means revival of classical culture, and as a specific culturological phenomenon, it means erudite education created by Hellens and developed by Romans, who recovered "humanitas" as global education. Italy was the first who helped humanists to contemplate on classical culture; and in post-medieval age, Italian humanists achieved a supreme measure of humanism through their "humanistic studies." We will try to point out good achievements of humanism erudite education in European culture in later epochs. Humanism leads man to turn over to world-after medieval stricture-and it becomes self-conscious revolution, what we can see in Latin literature till the 18th century. Rise of individualism, development of libraries and humanistic academies give chance to latin tradition in European literature as universal discipline, including erudite education in international corpus (Ragusa also). High-intellectual and latinized elites with humanistic state of mind develop complex spiritual inteligency with science requests in later epochs too. We will try to explain in which degree humanism, with its synthetic point of view, influences on later corpus of European literary themes and how great its actuallity is nowdays.
\end{abstract}

Keywords: humanism, latinism, erudition, studia humana, Italy, Ragusa, encyclopedism

\section{Introduction}

The period of humanistic inheritance stretches from antique to the end of the 18th century. Greek-Roman classic remains now and forever universal cultural model and top merit in literature and art in general. Every kind of distancing from it means slow decadence in values and yet until today this tradition remains encouraging. Nowadays, it is necessary to adjust humanistic inheritance to contemporary civilization, presenting its achievements in understandable way, but with great care to keep essential settings. According to this, it is important not to simplify humanistic values to bring them closer to today's education, which is mainly pure information, very distant from thorough, erudite education of humanistic provenience.

Today's civilization is in technical incline but in intellectual decadence. It can no longer go back to original principles of humanism, based among other upon Hellenic intellectualism, but it can try to uphold the awareness of today's man about value of humanistic disciplines which should not be neglected because if it does the spirituality in, itself would vanish in the future. Rapid decline of humanistic principles is plainly

Gordana Pokrajac, professor, Philosophical Faculty in Novi Sad, USA; main research fields: European Humanistic Literature and Philosophy. Email: tadzio.gordana@gmail.com. 
obvious after its short bloom at the end of 18th and the beginning of the 19th century. In our time, there is no more space for "silent education," as it is called by Goethe. One of the reasons concerns the "rational economy and science, as the foundation of modern civilization; it is the master of endless profitable professions tied to ever growing advance of technical power of the mankind" (Jaeger 2002). ${ }^{1}$ This kind of civilization growth obviously suppresses the cognition and free rise of human spirit, leading it to emptiness and furthering it away from basic antique meaning of "being humanist" which is a human being with its own spiritual values, the human being capable of feeling and understanding the value of literary or art work. Aiming to the rational complexity of the term humanism, ${ }^{2}$ and therefore its principles, it should be considered in different time contexts in which it aspires, to be able to see its existence through cultural history of the modern age. As a

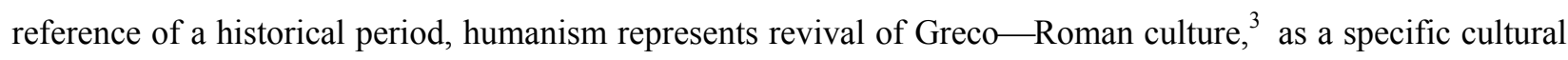
term based upon erudite education created by Helens and taken over by Romans thus discovering "humanistic education."

The complex problem of European literature and culture is represented by deep relationship between modern humanism and antic education. Unfortunately, in today's world, there is lack of interest for this kind of education although humanism is one of very important segments of modern culture based upon consciousness of new age people who adopt its influence, synthesis of Hellenic thought. Greeks with their Athens (school of Hellenes) and their thought form (Greek form of reflection ${ }^{5}$ ) are crucial.

If modern philosophers, who call themselves humanists, were more interested in history of mankind then they usually are, they would than say how deep importance has the fact that the ideal of culture originate in the same historical moment and in the same circle which create relativity teaching: The men is measure of all things. Doesn't it prove that all our theorizing about culture, education and ideal of human civilization is product of wise self limitation sophistic philosophy which directed the men to uphold from speculating about unfathomable and to concentrate to his perfection? ${ }^{6}$ (Jaeger 2002, 146)

The term of self-limitation, regarding perception of self-limitation, is the highest expression of free men in Homer's understanding of need to understand the true measure of its destiny. Questing the deepest spheres of human existence, Homer establishes humanistic principle, showing how human should design its existence in its own self-consciousness (center point is always upon human not so much gods).

\section{Ancient Inheritance in Renaissance}

Humanism represents constant and permanent principle in western culture, pervading it in historical continuity, with its inheritance of traditional antique and Christian education (from Byzantine to Caroling, Italian renaissance, classicism, enlightenment all to the beginning of the 19th century). Center of thought about classicism, in times of humanism and later, represents Italy. Italian humanists establish "humanistic studies," influencing in literary topics to latter epochs, primarily through development of comparative literature and interdisciplinary approach to studying literature. Latin is unavoidable ${ }^{8}$ as international language of all learned man, with whom the firmer connection between European literatures will consolidate stimulated by intellectually liberalism. In humanism, connection of philosophy with life is omnipresent - the everyday life problems which have been deliberated in renaissance, is given birth in humanistic period which is going to create philosophical notion of the men and the world and contradictory to the former, theological understanding.

As an essential notion in subtext off term "renaissance," humanism doesn't represent just merely going back to antique as a starting point for individual creation in new age, but true revival of classical spiritual and 
living experience creates a fertile starting point for emancipation of medieval authorities. After a holdfast of middle ages, humanism brings a human to an opening towards the world. Emphasizing the importance of his dignity human becomes its own revolutionary (as renaissance represents a long process of revolution conceived in humanism even before forming its attitude). Humanistic line of idea continually lasts thru the Middle Ages ${ }^{9}$ in spite latter renaissance endeavors to win independence from the church and metaphysics. The art is freed from church dogmas but it stays connected to scientific philosophy of its age, and so the artists and writers are making firmer relations with humanists. New renaissance society, with its ideology opposed to the former feudal system, is built on its own principle stimulated by intellectual individualism. This causes spiritual liberation from church dominance, so that the human as self-conscious individual in humanism—opposite the Middle Ages - becomes the goal and measure of all things. Humanists with their reflexive consciousness in literature reflect the individualism in the modern sense: The process will continue to develop; baroque will glorify the force of the self-expressive individuals, ${ }^{10}$ individual energy and spontaneity in finding the highest expression of human spirit. By setting up modus vivendi in latter epochs which essentially permeate the new spirit, humanism anticipates new element in conception of art which will echo to the period of Sturm and Drang, which is discovery of term genius ${ }^{11}$ and apprehension that the work of art is realization of independent personality who overcomes traditional theories and rules.

Humanism induces one important attainment which will permeate literature in the centuries to come, and that is an optimistic view to the future, which man's fear ${ }^{12}$ of afterlife exchanges for hope in this life and with fate in individual permeated with the spirit of the individualism. Those views are conceived in Dante, ${ }^{13}$ and later Petrarch ${ }^{14}$ and Boccaccio, ${ }^{15}$ who are in their attitudes given synthetic view of time in which they live and create, anticipate thus coming centuries based on humanistic principals of naturalism and humanism. Constant awareness of its own individuality despite engagement in general flows of their time and social events, will influence latter humanists: T. More, ${ }^{16}$ E. Rotterdam, ${ }^{17}$ T. Paracelsus, ${ }^{18}$ M. Montaigne, ${ }^{19}$ J. Böhme, ${ }^{20}$ G. Bruno, ${ }^{21}$ G. Galileo, ${ }^{22}$ and others who will convey the principles of their epoch to latter centuries.

Studying rise of individualism led slowly from the 14th century to its highest peak, is shown in cosmopolitism and integration of cultural legacy of mankind. This process shows from Dante's time to Goethe's term "die world literature" ${ }^{23}$ and permeating space and time in one allegorical-symbolical synchronistic in which the greatest works of literature coexist. Highly intellectual and latinized (according to Roman culture) elite, connected to humanistic and new platonic philosophy movement, develops spiritual complex intelligence which will constantly demand for Greek eruditio, fitting it in international literary frameworks. It all enables that Latinity overflows Europe and epitomizes literature as universal discipline, intending to implant erudite education in international frameworks. In the process, Ragusa participates from the rise to the fall of the Republic, beginning of the 19th century. The ideal that from Dubrovnik humanists aspire-like Dragicis ${ }^{24}$ and Crijevic ${ }^{25}$ - is to set up "humanistic studies" in the center of literary interests, as well as the creation in Latin which will enrich the classics. Considering that Latin literacy is flourishing, and that public and private libraries are opening, Dubrovnik bookstores supply by books from Italy (works of Ovid, Cato, Plautus, Cicero etc. in the 16th century open Academy of Concordant). The people of Ragusa, who read works of Latin writers in original, try to apply elegance of stile of Roman classics, going with the flow with progressive humanistic principles (like request for scientific character of their work), which will influence latter sum of European literary topics (less modern nowadays). 


\section{Humanistic Conception Towards the 18th Century}

European spirit of cosmopolitism which is encouraged by humanists, as heirs of Latin literary—artistic and philosophical heritage, reflects in works of authors in the 18th century: Voltaire, Russo, and above all Goethe. As one of the heirs of new type of humanistic poet, artist, and thinker - the descendant of renaissance universal man, Augustus Roman epoch all through Grand Siècle. After Winkelmann's ${ }^{26}$ delight with classics, Goethe discovers in Italy — source of monuments of culture from Roman times_virtues of classicism, which continues comparatively with continual need for knowledge ${ }^{27}$ and studying of antique cultural treasure. German historians from the period of Weimar classic ${ }^{28}$ live consumed by tendency for culture and education, as a few generations of writers from times of the first humanists. They consider civilized society-in view of humanistic and natural sciences renewal and new paganism ${ }^{29}$ —as real bearer of culture.

Goethe as a main exponent of humanistic inheritance of German culture emphasizes pedagogical ideal that finds its true fulfillment in culture of society in a whole and adjustment of humanistic postulates to the new age and modern opportunities. "Measure by whom the individual achievement fits in bourgeois life pattern becomes for it, the real criteria of the value of the work." ${ }^{30}$ Goethe's humanistic concept reflects in the fact that his poetic work - analog with Petrarch — is expanded only to the limited cultural layer, so that later his works are barely rear out of former intellectuals. His audience in Weimar are a few people (Duke, Duchess, Stein, Max Wieland), which is partly due to Goethe's attitude that the art is endeavor of the individual to preserve itself from destructive force of totality and majority. ${ }^{31}$ Humanistic features of the great "Olympian," heir of classic, reflecting thru his thoroughness as well as emphasizing (opposed to "Tempest and Instinct:" pre-romantism in Germany) form as expression of essence, as well as the idea itself of art work that doesn't coincide with merely external harmony of relations. Emphasizing the eternal form brings him in implicit relation with the Greek form of reflection. ${ }^{32}$ His own humanistic postulates Goethe, amongst others, presented in character of Wilhelm Meister. ${ }^{33}$

Breaking from medieval tradition encourages humanists to establish institution which will transpose new cultural patterns and harmoniously develop free minded views of some writers. The main role plays thorough education and rhetoric and grammar will not be inseparable from medieval manuals, but it will be based upon texts of Latin poets. In latter centuries, the heritage of literary education will bring up self-consciousness and dignity in every single creator, as it is promoted in the 15 th century Pico della Mirandola. ${ }^{34}$ Humanists will thrive in pedagogical work and few of them dedicate themselves to education of princes and church dignitaries, like G. Veronese, V. Da Feltre, ${ }^{35}$ and Dragisic. ${ }^{36}$ Erudite education has a tendency to replace medieval schools and guilds with academies and transform medieval universities like educational institutions with new cultural programs and opportunities of interactions between the writers via conversations and discussions, in that sense, they follow the classical tradition ${ }^{37}$ which will influence the development of the academies as a new model of a cultural institution and it will continue to advance in later centuries. In the renaissance, novelties concern possibilities of meeting the intellectuals and artists from different spheres of social praxis. Confrontation of thought in different interpretations of the texts enables new conclusions which urge further progress of humanistic thought. Giorgio Vasari, the first systematic mannerist and the founder of the first proper academy of arts through counterreformation and academism manifests different aspects of the same spiritual attitude. In three centuries of academism, it shows constant influence all through the 19th century, and it depends partly on strives of the traditions of the past times (based on the organized development), replacing by emphasizing 
classical models and eclectic copying of renaissance artist and thinkers. Compared with France, Italy concept of academy $^{38}$ never goes through formalizing, but it is in first elevation of more educated as well as financially independent above less educated writers and artists, thus saving basic humanistic code of erudite education. Although some academies due to the close ties with the patrons from ruling families depict foremost court culture $^{39}$ despite those who are independent from the court, to all of them precondition of academic acknowledgment is wide culture as a measure of social reputation. However educated people, who are riders of humanist's works, are $\mathrm{few}^{40}$ and-contrary to modern novelists—greatly depend upon favor of courts. Erudite education from the beginning represents precondition of academic acknowledgment and humanistic academies give incentive to development of numerous baroque academies in the 17th century, and distinction between literary from scientific academies although the interests permeated. Considering that the humanists continually point scientific character of their intellectual activity, mannerism gradually will shape concept of irrationalism of artistic creativity, which basically spurs out of the humanistic individualism; mannerists will represent the point that art can't be thought and artist must be born (G. Bruno points that rules are not source of poetry but the poetry is source of rule). In Baroque, things will modify in sense of even stronger guidance scientific thought according to artistic principles. City centers such as Rome, Florence, and Ferrara etc., are still centers of academies but differently from renaissance social and spiritual surroundings, absolutistic and counterreformation social context is slowly changing; it is pointed to the denial of certain critical attitudes of writers, who instigate certain humanistic action in fighting the dogmas, literary norms, and philosophical and scientific authorities. New intellectual consciousness in the 17th century causes distancing critical culture from one which is in the service of the government. At the end of the century, Academia of Arcadia was formed. ${ }^{41}$ It will develop in the 18th century and keep positive cultural heritage of humanistic provenience (restraint, reasonable attitudes - which after Montaigne emphasizes Descartes and Spinoza-educated taste, as well as inclusion of writers in contemporary social events.)

The 17th century reflects humanistic heritage through new aristocratic culture of the society and renewal of former chivalrous notion of morality, known from Castiglione's Courtier: education, politeness, decorum etc.... Special feature of creators in Grand Siècle is cosmopolitism and endeavor to see themselves-like ancient Romans - as citizens of the world, represented in Racine's tragedies, works of Boileau-Despréaux, Bossuet, and La Rochefoucauld. Urban environments such as Paris and Versailles are stages where the whole spiritual life is developed, analog with humanistic postulates from previous centuries in Italy. What at the end of the century stands out of the basic humanistic concept is suppression of individuality, considering that absolutism creates elite which admits its debt to the ancient times but its academism demands respect of the rules and postulates of classicistic aesthetics ${ }^{42}$ and this opposes the basic classical and renaissance demands. Compared with French, Italian academic theory in the 17th century was not so rigid, it originated from classic tradition of humanism, Latin and unique activity; ${ }^{43}$ France in frame of its precious salons gathered connoisseurs of arts and very well educated people but at the same time the phenomenon of preciousness furthered it away from the original humanistic principles.

In the 18th century, the connection between literature and philosophy was emphasized more and more; the activity of academies continued as the work of humanistic gymnasiums, which replaced medieval Latin schools; this was made by the great contribution in studying ancient languages, made by Humboldt, who connected the languages with other cultural contributions and so advanced modern humanistic education. In studying classical 
languages, "the highest formal education of the spirit is connected with fundaments of organic - historical build of modern cultural consciousness, with its basic form, which is the measure for plunging in depts. of irrational and heights of surreal" (V. Jaeger 2002). ${ }^{44}$ Although the 18 th century academies will be in decline in views of basic humanistic principles, writers and thinkers will be actively tied to problems that originally occupy intellectuals of the 18 th century. Academy is now ${ }^{45}$ - differently from humanistic designed academies - more liberal, considering that the members are no more limited just to erudite. The reason lies in the fact that it realizes that "only by accepting so liberal attitude can survive that period of renovation and upheaval" (N. Pevsner 1940). ${ }^{46}$ The patrons now come from outskirts of courts and have not so sophisticated taste, nor are they connoisseurs of literature and art as were humanistic patrons from previous period. The end of predominance of academy comes finally with French revolution 1791 when begins the democratization in arts.

During rococo-when art for middle class develops, it is apparent distancing from elite cultures renaissance and baroque; there is no more strive to point out clear structure and objective representation in frame of formal ways of expression but to express emotional contest in middle class literature. Although the old aristocratic tradition weakens, it is not stopped, because writers in the 18th century can again turn to their patrons, which represents revival of humanistic tradition; however this happens less because there is resistance towards the classicistic ${ }^{47}$ principles of the 14 th century in its strives towards normative principals.

Humanists are the first to open literature - artistic activity as a main part of intellectual and moral culture, and besides the development of the academies, special importance has humanistic libraries ${ }^{48}$ which contribute enlightenment role of literature in latter centuries, thanks to humanists and their patrons in the 15th century stars to structure modern type of libraries. At the beginning when great private libraries develop, they are different from medieval type of cathedral private libraries, implementing novelties like finding and gathering of original manuscripts $^{49}$ (Florentine nobleman Pala Strozzi has a noble idea that his collection of fundamental Greek texts brought from Constantinople out to everybody's disposal so that people draw wisdom from it). This humanistic inheritance will continue in the 18th century taking care of very precise systematization in order to be as accurate as possible in structuring library institutions and reaching the highest values in that way (special guidebooks are created to make library system more accurate and to restore ancient documents).

Encyclopedic learning and practical multiplicity—as the part of the humanistic principles - basically represent medieval ideal, although aesthetic autonomy in renaissance points out artistic endeavor to free from scholastic thought. Humanists pointed scientific character of their intellectual activity and interest in outside world, and artistic truth led to addiction from scientific measures; however, they could not neglect positive inheritance of medieval teachings especially in the 15th century. With victory of humanistic concept of culture and with cultural activity of universal man, the late renaissance and baroque scientific thought will form according to artistic principles. In time the continuous fight of critical mind against the authority of the dogma, which lasts from times of the first humanists (when antithesis doesn't reflect only to the church but to the antique as well ${ }^{50}$ ), will have its peak in the 18th century; now the light of rationality will uplift the inheritance of humanism even stronger developing literary activity and its principles inseparable from philosophy.

In this period, the stronghold of enlightenment literature and culture becomes France in which shows the basic principles of humanistic views of men spirituality: strive to the truth based upon reasonable interpretation of reality; rejection of prejudices and emphasis of positive knowledge; natural sciences are coupled with new philosophy of nature; free mind is stated in activity of those writers who are simultaneous and philosophers (Marivaux $^{51}$ and Marquis de Sade $^{52}$ ), but the most in the work of the encyclopedists. Encyclopedia ${ }^{53}$ is 
collective and the greatest achievement of French enlightenment, which synthesizes all the progressive spiritual tendencies of the 18th century. Denis Diderot—main editor of humanistic sciences and crafts - is the author of Prospectus of the Encyclopedia (which contains D'Alambert's editorial discussion) and according to his blueprints, this work will give unique picture and review of human acknowledgments, which are divaricated from the same tree. ${ }^{54}$ Encyclopedists sow the importance of collecting, critical enlightenment, and scientific representation of entire cultural inheritance, continue thus humanistic mission and engirdle it by presenting new age exact sciences, inseparable from its practical use. They conducts in praxis very important humanistic principle which refers to removal from prejudice and superstition, by focusing the spirituality and education on the problems of the contemporary men, making changes for final breaking of medieval ideology and absolutism of state. Encyclopedists play extremely important role in development of literary, scientific, political, and philosophical views of progressive European culture, based upon humanistic postulates. Progressive cultural, social, and philosophical role of these writers and thinkers is noticeable even nowadays in France, where they are originated, but in other parts of Europe, heirs example serves as humanistic stimulus in great fight for cultural and political freedom.

Humanists strive to purify Christianity with the help of philosophy and the life according to models of antique world, reacting to ideal and civilization exhaustion of medieval times; this spirit originates works inspired by antique aesthetics and written in classical Latin, modeled by great Roman writers (Horatio, Cato, Cicero etc.), shaping gradually new Latin literature. Subjecting the whole cultural inheritance to their own critical spirit and polemic elucidation according to men, opens the road to further affirmation and theoretical shaping of principal human dignity, which coincides with the rise of citizenry in time of new social and political order (city government). Prevalence of Latin according to literary inheritance of Roman classics, humanism represents the great turning point of modern ages, which will have influence from the end of the 18 th to the beginning of the 19th century.

\section{Conclusion}

In long historical continuity of reflection of rules of literary creation, ${ }^{55}$ humanistic studies (as synthesis of inheritance of classical culture, literature, pedagogy, philosophy, oratory) give contribution to the shaping of the modern men. Bearer of the humanistic culture and architect of the new literary principals are the new type of writer who writes with chosen prose style, builds polite strophe, translates from Greek to Latin, and regards the polished style; he is a professional writer who lives from his literary, translator and teaching activity, and humanistic individualism which cheats consciousness of independence of different forms of intellectual expression, influenced the representation of the artist and his originality; their interaction reflects in help that humanists give as learned advisers in interpretation of mythological and historical subjects. ${ }^{56}$ Humanists begin the process of fitting art in integral part of intellectual and moral culture, whereby the renewal of antique is the mean of liberating the human from holdfasts of medievalism and way to the new areas of nature and human activity; they search for deeper source of knowledge, and this search flows as to nowadays, caring the echoed of awakening of human self-consciousness, critical relation toward science and philosophy and the demand for autonomy of scientific work of humanistic provenience. Humanistic inheritance brings multiple positive achievements to the European culture and literature and refers to humanistic education of writers, occurrence of schools and academies - thru which Latinity overflows the Europe and develops international literature - as well as humanistic principles which will have echoed in latter style formations until today; of crucial 
importance is: erudite, individualism, and autonomy in literary creation, principal of harmony originated from classical philosophy and literature and transposed in new age philosophy, ${ }^{57}$ founding the libraries and archives which are key to understanding the essential of all that come in European new age cultural history after the humanistic turning point, including the modern age.

\section{Notes}

1. V. Jaeger, Humanism and Theology, Belgrade, 2002, 6.

2. The expression humanism is quite new. It was created by historian in 19th century which was exploring renaissance humanists. Italian humanists by humanistic education were explicitly pointing to one of their greatest row model and authority, from whom they took the expression, Cicero.

3. This culture permeates overall humanistic poetics given by tradition of Greek and Latin literature; what was created by certain concrete conditions, as well as individual abilities of prominent people, was regarded as a product of immanent natural laws, while literately types of Greek poetry and artistic prose, "considered to be natural types of literature" (W. Wiliamowitz-Mollendorf, The Greek Ancient Literature, in Nowadays Culture I, VIII, Berlin-Leipzig, 1905, 112).

4. Romans founded their system of education based upon Greek system. It was humanistic education that they created that kept the legacy of Hellenic cultural ideas. They tried to firm humanism as a permanent principle upon which the latter European culture will develop. Adopting "Greek erudition," Romans became erudite capable of adopting Greek individualization and comprehend the essence of Hellenism which will grow into humanism.

5. Latin term humanistic education— to which Cicero in his works gives educational meaning — concurs with Greek paideia. Aulus Gelius notices this in second century B.C. (R. Reitzenstein, Humanistic Development and Work in Ancient Time, Strasburg, 1907).

6. V. Jaeger, ibid., 146.

7. Eugenio Garin, Italian Humanism, Novi Sad, 1988.

8. Inheritance of humanism reflects in studying of ancient languages, primarily Latin and then Greek. These views even before V. Humboldt—who at the end of the 18th century emphasized spiritual and formal values of ancient languages—emphasize Pico della Mirandola (Speech of Human Dignity, B. Cicognani, Firenze, 1942), Erasmus Rotterdam (Praise of Folly, Zagreb, 1921) and through Erasmus work, François Rabelais, from the mouth of his Gargantua in famous novel Gargantua and Pantagruel, speaks of importance of learning: Latin, Greek, Haldeic, and Hebrew (A. Leonarduzzi, F. Rabelais, and his pedagogical prospect, Trieste, 1966).

9. When Erasmus Rotterdam and humanists of his time defined their purpose of education as "sapiens et eloquens pietas," they continued to build medieval thought. Erasmus was inclined to Thomas Aquinas — which shows in its work - but not to scholastic tradition which was critically viewed in his time (U. Eco, The Aesthetics of Thomas Aquinas, Zagreb, 2001). Therefore, Erasmus strived to put an ascent to the humanistic education—not the dogma—and to view the Christian principles through new, classical prism.

10. H. Baker, The Image of Man. A Study of the Idea of Human Dignity in Classical Antiquity, the Middle Ages, and the Renaissance, New York, 1961.

11. This term developed in enlightenment movement in 18th century when the feeling of individuality in literary creativity reviled itself in the ideal of genius, who wasn't, in his creative originality, bound to any ground rules formed ahead. Titanic spirit of Prometheus, which lifted people to the higher level of culture, matches the creator-genius, who in its work shapes real men, not caring for the rules. This basically coincides with primary principles of the humanists in 14th century, who follow the poetics of inspiration and neoplatonic conception of poetic creation.

12. J. Delimo, Sin and Fear — Creating the Guilt Feeling in West From 14th-18th Century, I-II, Novi Sad, 1986.

13. Through The Divine Comedy, ("book of life and truth"), Dante represented the human with all its abilities in context of 13th century religious believes. He established the idea of individualism, which will in renaissance, became one of basic terms of progress. Sense of authentic human personality by Dante is close to naturalism of new age which derived from humanism, which basic settings were enforced by this Italian universal man in his work. In his views of afterlife, the human, bracing and credible, anticipate in the late years of Middle ages humanity characteristic to new age men.

14. Petrarch in his whole opus discovers depth of the antique reflexive word and develops principles of Christian humanism, trying to establish continuity between classical and Christian thought, he attached to great models Latin (Cicero-in view of synthesis of classical moral thought and creation in Latin, Seneca- thru whom he introduced stoic tradition based on uplifting roman virtue), and Christian, like St. Augustine who reveled to him continuity and concordance of platonic thought and Christian tradition.

15. As an out-front humanist free minded and critically guided towards medieval spiritualism, Boccaccio sets foundations of realism and naturalism in approach to world and men. This naturalistic approach-which in renaissance will get scientific character — was begotten in middle ages, and was developed in Boccaccio's time when one tried to explain the world as given by nature, and to fit in all segments of sensual experience in one rationally organized system. 
16. English humanist followed the thought of possibility of rational influence to the change of unjust full social circumstances primarily as the concept of ideas from Plato's The State and Aristotle's political realism from The Politics. He also followed the roman state system and in his work he influenced its use in latter times. Mores' contribution to humanistic ideas reflects in his optimistic stance about the freedom of individual, its dignity and possible versatile growth (T. More The Utopia, Of a Republic's Best State and of the New Island Utopia, Belgrade, 1952).

17. Inspired by classical studies, Erasmus promoted Christian humanism aiming to overcome medieval and establishing new views which were brought by the spirit of time in which he lived in (Roland H. Bainton, Erasmo in Christianity, Firenze, 1970). "He represented the ideal of new, free humanity, which was supposed to be based upon moral responsibility of the men. He was one of spiritual leaders of young humanism, and opposed to official authority he didn't and therefore different from other humanists, confronted any other authority but severely criticized the times he lived in and showed the ways in which the new society will follow" (Vladimir Filipović, Philosophy of Renaissance, Zagreb, 1982, 46).

18. Humanistic spirit of Theophrastus von Hohenheim Paracelsus reflect in his critic of formal knowledge (Goethe will, in the beginning of the 19th century, form in Faust in the character of Wagner and phenomenon of Wagnerism), and fruitless scholastic wisdom by his method of experience and fight for individual thinking and personal beliefs, is forerunner of future humanistic oriented thinkers in 17th and 18th century. In Paracelsus's thinking, the important role has comparation with the book and "from the light of the Nature must come the enlightenment so that books about nature could be understand, because without enlightenment, there is no philosophers or naturalists (E. R. Curtius, European Literature and Latin Middle Ages, Belgrade, 1996, 526). The metaphor of the book took over renaissance humanists, Montaigne, and Bacon.

19. Montaigne's Essays in whole represents the ideas of humanistic self consciousness, optimism, and temperance and its author with his skepticism and ant dogmatism anticipate methodical skepticism of Descartes who will be essential with the humanists interested in autonomy of sciences in 17th and 18th century. Like Montaigne's ideal of "humanizing the world "as a legacy to future epochs, they presented new scientific methods based upon principals of humanism, modern even nowadays.

20. Jacob Böhme was a mystic living at the crossroad of 16th and 17th century. He based his work upon tradition of Meister Eckhart from 14th century (F. Copleston, History of Philosophy —Late Middle Ages and Renaissance Philosophy, Belgrade, 1994) Boehme strives that in spirit of "religious humanism" induce independence of human spirit, putting the men in the center of interest so that he can scientifically question sense of the world contained in faith. The man is the plain of permeating the heaven and the earth, spirit and body, and in everlasting antagonism of good versus evil, in order to overcome the evil; Boehme presents special expression of self-conscious humanistic spirit, which urge liberation of one's individuality of medieval holdfasts.

21. Bruno's deeply humanistic philosophical culture reveled in his thorough studying of antique philosophers, scholastics, Arabian thinkers (Averroes and Avicenna), as well as Italian humanists who encouraged in him self-conscious and positive thought about human creativity in future (G. Aquilecchia, Giordano Bruno, Roma, 1971). Renaissance humanism reflects in his anthropological conception by which the men is creator - self-creator - architect of his own happiness and responsible for his own destiny, because he has the free will to decide (free will), analog to the teachings of Pico della Mirandola (E. Garin, Giovanni Pico della Mirandola, Firenze, 1973). By synthesis of classical thought and personal religious feeling, Bruno anticipated pantheistic concept of the world (in later centuries Spinoza will apply it in his Ethics, Russo in his philosophical system and Goethe in Faustus).

22. Galileo fought for autonomous scientific research based upon humanistic principals of synthetic view in the picture of universe at whole. With critical philosophic thought and empirical argumentation he attached to achievements of humanism, by offering with his experimental method contribution of further progress of humanistic postulates in science (A. C. Crombie, Augustine to Galileo. The History of Science, a.d.400-1650. London, 1952).

23. J. W. Goethe. Literary Essays, Belgrade, 1959.

24. In Dubrovnik (Ragusa) created Djuradj Dragisic (Georgius Benignus Argentinensis Salviatus, around 1450-1520), writer, philosopher, and theologian who merged all the characteristic of a humanist and Latinist. He also was a great cosmopolitan; he studied in Rome, Florence, Bologna, Pavia, Urbino, Ferrara, Paris, and Oxford. He belonged to platonic circle which gathered cardinal Visarion, and later became member of famous platonistic academy of Georgius Gemistos Plethon (Byzantine), Dragisic while in Ragusa, wrote dialogues (Georgius Benignus, About Nature of Angels and Spirits, Florence, 1499), and this choice of genre is one of the heritage of humanistic tradition to whom he contributed with precise, systematic, and valuable culturally-historical material.

25. The idea of renewing antique in Dubrovnik literature was seen thru rehabilitation of the topics, ideas and forms of Greek and Latin literature. The ideal strived by humanist like Ilija Crijevic (Aelius Lampridius Cervinus, 1463-1520), is presenting humanistic studies in the center of literary interest and creation in Latin. With his work, this greatest Dubrovnik humanist of 15th century, uplifted classical literature to the level to which all the latter Dubrovnik writers will strive, from renaissance to 18 th century. As a member of humanistic academy of Pomponius Laetus - and Crowned Poet - he tried, by studying antique texts, to enrich Latin, and to apply vocabulary richness and elegance of style oh roman classics in his works. Heritage of humanistic erudite and appreciated intellectual elitism, characteristic to humanists, reflected in Crijevic's consistent evoking of classical sources (About Epidaurus, Elegies Dedicated to Flavia, About Comedy and New Satyra, Apology to Plautus).

26. Winckelmann is - with Lessing, Herder, and Goethe - supported and promoted new cult of antique. The trip to Italy was important part of education of every young cosmopolite, who developed its intellectual abilities from direct contact with monuments of classical art in Italy. Those authors saw in Hellenic and roman models examples of true humanity which after the troubling times they lived in (between 18th and 19th century) will never be reached, and which coincided with the rise of archeology and passion for gathering and studying the antiquities. In Goethe's biographical essay about Winkelmann (Winkelmann 
and his Age, 1805) describes classics as "the highest maturity of earthly perfection" (F. Martini, History of German Literature, Belgrade, 1971, 266)

27. In concordance with Aristotle's sentence about men's highest search for knowledge, in the beginning of Metaphysics. (Aristotle, Metaphysics, trans., Tomislav Ladan, Zagreb, 1988).

28. In time of Goethe's and Schiller's forming of new classical aesthetics, Weimar became the capital of culture with the motto that universal cultural model and top measure of art represents only antique. That was the starting point of the new humanist who, by classic ideal, characterize noble simplicity and "tranquil grandness" (S. Grubachich, History of German Culture, Belgrade, 2001).

29. P. Gay, The Enlightenment: An Interpretation. The Rise of Modern Paganism, New York, 1968.

30. A. Hauser, Social History of Art and Literature, II, Belgrade, 1962, 115.

31. He stated special intellectual-aristocratic affinities at the curt in Weimar, representing one of the most consistent rationalists in Germany not inclined to mysticism and/or all the shapes and forms of reactionary forces. Considering that medieval literature - which owed its versatility to the Latin language — was focused and limited to the clerical class, Goethe continued to the developing line of rococo and baroque, which mainly was focused to aristocratic circles. He emphasized the great work of poetic creation (which, in Faust, stands out what is representative and stands above nature and banality of life) and demanded from the artist professional reliability.

32. About this phenomenon writes W. Jaeger (Paideia, Ideals of Greek Culture, I-III, Oxford, New York, 1939-1943).

33. Contents of the novel about Wilchelm Meister move from individualistic and humanistic attitudes towards life to experience of intellectual community. It shows progressively moving from aesthetic and contemplative position against social contest, towards active and useful participation of the individual in society (J. W. Goethe, Wilchelm Meister, Zagreb, 1960).

34. P. della Mirandola, ibid..

35. Gavrino Veronese and Vittorino da Feltre lived in between 15th and 16th century and their work as humanists — pedagogues at firs will be applied to aristocracy under which patronage they could work in the fields of literature and diplomacy.

36. From Dubrovnik humanist Giorgio Dragisic (15th-16th Century) was a teacher of the duke of Urbino son and the great patron of arts Federico de Montefeltro (later famous military leader) as well as educated patron of arts pope Leo X (Giovanni Medici, son of Lorenzo the Magnificent).

37. Academies at first were the mean of liberating the artists from the guilds and their elevation from pure craftsmanship. Later the canons of educations moved towards one ideal, which will be developed in France in 17 th century.

38. Plato's philosophical Schools in the yards of Academe, influenced forming of gatherings which will not were tied to public action with adopted system of rules.

39. One of the most respected academies was in Florentine's "Platonic Accademy" (A. Della Torre, History of the Platonic Accademy of Florence, Firenze, 1902) and "Pomponiana" in Rome, which was lead by Julius Pomponius Leto, and in which was crowned by the title crowned poeta greatest humanist from Dubrovnik-Ilija Crijević (Petar Kolendić, Coronation of Ilija Crijevic in Academy of Pomponio Leto, Anthology, Serbian academy of science, Belgrade, 1951, X, 1, 65-77).

39. Baldesar Castiglione especially contributed shaping of ideals of personality in his Courtier (1528)-cosmopolitan, equally developed physically and mentally, with great experience in poetic and artistic craft, connoisseur of literature, painting, music, science and other areas of human praxis. Heirs of the humanists in 18th century, who were theoretic of the new outlooks, came mostly from aristocratic circles, but were not so much alienated from contemporaries and showed stronger ties with reality. "As spiritual leaders of the century they prevailed theoretically determination of their social status and stand to a sine of the new historical forces that were coming" (D. Pejovic, French Enlightenment Philosophy, Zagreb, 1982, 11). Inspire, they spent their lives in courts, had courtly manners, respected decorum and represented model given in Castiglione's Courtier. Humanistic erudition and eloquence became the most prominent features of philosophers and patronage was one of precondition for humanism as free literary profession.

40. Humanists didn't belong to strictly specified; culturally and professionally equal social class. There were also secular people, clerics, merchants, and teachers, lawyers, scientists which will be case in times to come. What is common is that they all grow up in the city. This shows one of limitation of the humanism-demanding educated men, connoisseurs of antique and ancient languages - in its circle include only wealthy individuals who lived in cities. Most population in aeries enveloped by humanism — still lived like in middle ages. This paradox is one of the great weaknesses of humanism.

41. It was founded at the end of the 17 th century in Rome, stimulated by work of writers (G. M. Crescimbeni, G. V. Gravino, G. F. Zappi, and V. Leoni) who tried to restore classical values in context of the story of the roman Arcadia, so that literature will again have the same influence which had in renaissance. The goal was to fight against the bad taste (left as a legacy from baroque) and to restore simplicity and clarity to the poetry, according to roman and Italian classical tradition. The ideals were Theocrat, Vergil and humanist from Naples Sanazzaro-founder of Arcadia (1504).

42. Classicists encouraged the growth of universal "aesthetics of concusses," taking care of built, sophisticated taste and trying to make rationalistic component bust the flourishing of the literary culture, which is one of key classicistic postulates of humanistic provenience.

43. Classical humanistic taste was still nourished and highly educated individuals-educated upon classical science - continue the tradition of humanism thru affinities towards classical history and mythology which they reflect in literature. 
44. V. Jaeger, Humanism and Theology, 2002, 22.

45. Academy was still in XVIII "firmly holding traditional hierarchy of genres and continues to look with contempt to "petit genres." But it was not more dogmatic from educated audience in general, which in theory at least upheld classical doctrine" (A. Hauser, Social History of Art and Literature, II, Belgrade, 1962, 21-22).

46. N. Pevsner, Academies of Art, Cambridge, 1940, 108.

47. In 18th century inside, classicism develops "archeological classicism" as renewal of the interest for the antique and antiquities (stimulus given by excavation in Pompeii and Herculaneum in the middle of the century); it is important to notice the new interest in humanistic inheritance in art which reflects in firmer, more serious and objective measure of style. This new classicistic movement becomes leading in Rome, from where it spreads throughout Europe and imitating classical antiquities becomes self-sufficient and turns in academic art.

48. G. Avanzi, Humanistic and Renaissance Books, Bookshops and Libreries, Roma, 1951.

49. At first, the antique texts were gathered and ruling families and wealthy citizen in Italy founded libraries desiring to give opportunity to minority of educated people to study, translate and write discussions of precious writings of classical authors; humanists in position of librarians possessed necessary knowledge from librarian work.

50. Spirit of antithesis in regards to antique shows in the attitude that it did not represent the unity of the views but the fight of two opposite sides_-Platonism and Aristotelism.

51. Pierre Marivaux showed philosophical and scientific meticulousness as well as affinity and respect towards antique. His The Travesty of Telemach (1714) is "real small revolution in direction of realistic storytelling and reasonable morality" (G. Vidan, Eighteen Century, History of World Literature, 3, Zagreb, 1982, 310-313).

52. Marquise de Sad considered himself a "philosopher" and he, like the other philosophers of 18th century knew and reflected about nature (G. Vidan, Eighteen Century, History of World Literature, 3, Zagreb, 1982, 368).

53. Rationalistic Encyclopedia and Dictionary of Science, Arts and, Skills, Paris, 1751-1772, 28 Vols; Supplement, Amsterdam, 1776-1777, 5 Vols; analytical table, Paris, 1780, 2 Vols).

54. D. Pejovic, French Enlightenment Philosophy, Zagreb, 1982.

55. Literary theories based upon humanism and with echoed in modern time are inseparable from Horatio's poetic principals, which will through renaissance theoretical discussions-like The Books About Poetic Art III, 1527 and classicistic About Poetic Art, 1674 influence the flow of humanistic theoretical principals of literature until the end of 18th century.

56. To the artists humanists guarantied intellectual position, seeing value of art as means of propaganda for those ideas upon their one intellectual predominance was based upon. From this relation originated the concept of unity of art, which today we take for granted but was unknown before renaissance (A. Hauser, Social History of Art and Literature, I, Belgrade, 1962).

57. Humanistic principle of harmony anticipated the new age materialistic thought; Johann Kepler in Harmony of the World reflects humanistic view of universe as neoplatonistic picture of divine mind achieved in nature, while humanistic naturalism in research of nature and human spirit by empirical scientific method encourage development of true philosophy of nature.

\section{Works Cited}

Alistair, Cameron. Augustine to Galileo. The History of Science. A.D. 400-1650. London: Falcon Educational Books, 1952.

Arnold, Hauser. Social History of Art and Literature I-II. Belgrade: Kultura, 1962.

---. Poetics of Humanism and Renaissance I-II. Belgrade: Prosveta, 1963.

Alessandro, Leonarduzzi. F. Rabelais and His Pedagogical Perspective. Trieste: Università degli Studi, 1966.

Aristotle. Metaphysics. Trans., T. Ladan. Zagreb: Liber, 1988.

Baldesar, Castiglione. Courtier. Zagreb: CEKADE, 1986.

Danilo, Pejović. French Enlightenment Philosophy. Zagreb: Matica hrvatska, 1982.

Erasmus, Rotterdam. The Praise of Folly. Zagreb: Binoza, 1921.

---. Latin Works of Aelius Lampridius Cervinus IV. 1934, XVIII.

Eugenio, Garin. Culture of Renaissance. Belgrade: Nolit, 1982.

---. Giovanni Pico della Mirandola. Florence: Storia e Letteratura, 1937.

---. Italian Humanism. Novi Sad: KZNS, 1988.

---. The Man of Renaissance. Belgrade: Clio, 2005.

Ernst, Robert Curtius. European Literature and Latin Middle Ages. Belgrade: SKZ, 1996.

Frederic, Copleston Koplstone. History of Philosophy — Late Middle Ages and Renaissance Philosophy. Belgrade: BIGZ, 1994.

François, Rabelais. Gargantua and Pantagruel I-II. Belgrade: Kultura, 1989.

Fritz, Martini. History of German Literature. Belgrade: Nolit, 1971.

Giovanni Pico della Mirandola. Speech About Human Dignity. Florence: Vallecchi Editore, 1942.

Giannetto, Avanzi. Humanistic and Renaissance Books, Bookshops, and Libreries. Roma: Autoedizione, 1951.

Giovanni, Aquilecchia. Giordano Bruno. Roma: Instituto 1819 della Enciclopedia italiana, 1971. 
Hersghel, Baker. The Image of Man. A Study of the Idea of Human Dignity in Classical Antiquity, the Middle Ages, and the Renaissance. New York: Harper Torch Books, 1961.

Ivo, Vidan. "Eighteenth Century in the History of World Literature 3." Zagreb: Liber, 1968. 71-97.

Ivica, Martinović. Genres in Croatian Philosophical Heritage From the 15th to 18th Century. Split: Philosophical Faculty of Split, 2011.

Johann, Wolfgang Goethe. Essays of Literature and Art. Belgrade: Rad, 1959.

---. Wilhelm Meister. Zagreb: Matica hrvatska, 1960.

Jean, Delumeau. Sin and Fear —Creating the Feeling of Guilt in the West From XIV-XVII Century I-II, Novi Sad: KZNS, Dnevnik, 1986.

Jacob, Burkhart. The Culture of Renaissance in Italy. Belgrade: Dereta, 1991.

Kalist, Tadin. The work of Elias Lampridius Cervinus. Dubrovnik: Dubrovnik, 1907.

Marin, Franicevic. "Sources and Courses of our Renaissance Literature.” Zagreb: Skolska knjiga, 1968. 71-97.

Michel, de Montaigne. Essays_Book I. Zagreb: Demetra, 1998.

Nicolaus, Pevsner. Academies of Art. Cambridge: Cambridge University Press, 1940.

Petar, Kolendic. Coronation of Aelius Cervinus in Academia of Pomponius Laetus. Belgrade: SAN, Belgrade, 1951. X, 1, 65-77.

Peter, Gay. The Enlightenment: An Interpretation. The Rise of Modern Paganism. New York: Archon Books, 1968.

Roland, Bainton. Erasmo in Christianity. Firenze: Sansoni, 1970.

Richard, August Reizenstein. Humanistic Development and Work in Ancient Time. Strasburg: J. H. E. Heits, 1907.

Slobodan, Grubacic. The History of German Culture. Belgrade: IK Zoran Stojanović, 2001.

Thomas, More. Utopia. Belgrade: Utopia, 1952.

Torre, Arnaldo della. History of Florentine Academy. Florence: G. Carnesecchi, 1902.

Urlih, von Willamovich-Möllendorf. The Greek Ancient Literature in Nowadays Culture. Die Kultur der Gegenwart 1, VIII. Berlin-Leipzig, ed., Paul Hinneberg, 1905.

Umberto, Ecco. Aesthetic Problems in the Work of Thomas Aquinas. Zagreb: Globus, 2001.

Vladimir, Filipovic. The Philosophy of Renaissance. Zagreb: Matica hrvatska, 1982.

Werner, Jaeger. Paideia, Ideals of Greek Culture I-III. New York: Oxford University Press, 1939-1943.

Werner, Jaeger. Humanism and Theology. Belgrade: Plato, 2002. 